\title{
RUBENS VALERIANO FURTADO FABRÍCIO DA SILVA
}

No dia 14 de junho de 2012 faleceu, em Santa Maria, aos 84 anos de idade, o Dr. Rubens Valeriano Furtado Fabrício da Silva, grande amigo e um dos primeiros apoiadores da revista Balduinia, atento admirador, que era, de tudo o que diz respeito à cultura, história e ciências no Rio Grande do Sul.

Natural de Bossoroca, na região das Missões, Fabrício era carinhosamente chamado de "Barão" por seus inúmeros amigos. Em sua formação superior, cursou alguns anos de Medicina na Universidad de la Republica (Montevidéu Uruguai), mas graduou-se pela Faculdade de Santa Maria, fundada em 1954, como extensão da UFRGS. Na sequência, especializou-se em Dermatologia em Buenos Aires e concluiu, com louvor, o $2^{\circ}$ Curso de Pós-Graduação em Medicina Tropical, pelo renomado Instituto de Medicina Tropical de São Paulo.

De volta a Santa Maria, assumiu a cátedra de Dermatologia na UFSM, onde ajudou a formar mais de 4.000 profissionais. De acordo com ex-alunos, sua aulas eram fortemente influenciadas pelo método francês de ensino e verdadeiramente magistrais, próprias de um catedrático da velha estirpe, que sabia aliar, com invulgar modéstia e naturalidade, elevada erudição e aforismos regionais, para deleite de toda a turma.

Na década de 1970, como médico responsável pelo Dispensário da Casa de Saúde, promoveu uma campanha histórica pela erradicação da hanseníase no Centro-Oeste do Estado. Em Santa Maria, Fabrício também trabalhou nos hospitais Astrogildo de Azevedo, Universitário e da Brigada Militar, deixando em todos os locais em que atuou a imagem de profissional competente, ético e, sobretudo, humano.
Além de uma vida profissional exemplar e de um amor irrestrito à medicina, Fabrício foi, antes de tudo, um ser humano íntegro e apaixonado pela vida. Cultivou incontáveis amigos, com os quais gostava de confraternizar em longas conversas regadas a tintos encorpados e brancos espirituosos. Talvez por sua origem missioneira, apreciava com gosto um bom churrasco e se gabava de fazer o melhor carreteiro do Rio Grande do Sul, com charque trazido de sua amada Bossoroca.

Profundo apreciador das artes, sobretudo da literatura, declamava trechos inteiros de Antonio Chimango, Martin Fierro e poemas de Manuel Bandeira. Apaixonado pela leitura, conhecia a fundo a história gaúcha, especialmente a saga missioneira e as várias revoluções que eclodiram no Estado.

Seu amor pelas coisas do Rio Grande levouo, já com idade avançada, a cursar a disciplina de Fitogeografia na Universidade Federal de Santa Maria, como aluno especial e com excepcional aproveitamento. E foi com grande satisfação que privamos de sua companhia nos mais distantes rincões do Estado, em memoráveis excursões! Como homem verdadeiramente sábio, Fabrício apreciava o convívio com os jovens colegas de turma; para estes, com toda a certeza, ficou um exemplo concreto da necessária e permanente busca pelo conhecimento, da valorização da alta cultura e da própria vida, como bem-maior.

Ao grande e inesquecível amigo, o corpo editorial de Balduinia registra um sentido preito de admiração e de saudade.

José Newton Cardoso Marchiori \& Ricardo Ritzel 


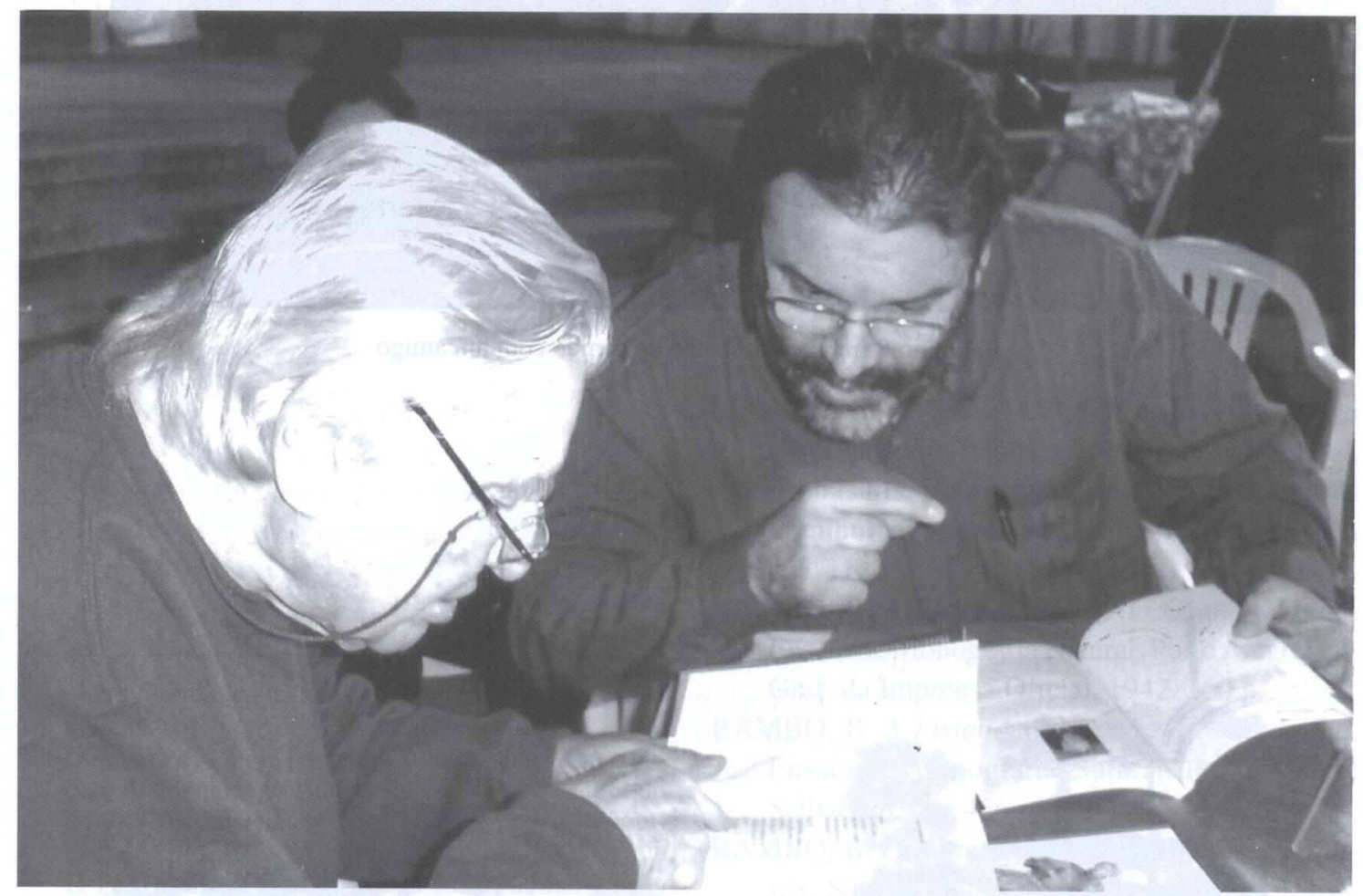

Dr. Rubens Fabrício (à esquerda) e o editor de Balduinia na Feira do Livro de Santa Maria (maio de 2009) 